\title{
AKTIVITAS PENGHIMPUNAN DAN PENYALURAN DANA BERDASARKAN KONSEP MUDHARABAH DI BANK NAGARI CABANG SYARIAH PADANG
}

\author{
Riyan Suarman Pili, Jhon Fernos \\ Akademi Keuangan Perbankan "Pembangunan" Padang \\ Jhonfernos@akbpstie.ac.id
}

\begin{abstract}
Mudharabah or qirad is the delivery of a specific property to someone utuk cultivated. Profits of halved in accordance with the terms agreed upon. While the harm is only charged to the owners of capital, while implementing only bear losses on labor (effort) and the time.
\end{abstract}

The collection is the process of collecting funds from the public that the excess funds, the fund raising such as checking, savings, and time deposits, the distribution is the process of distribution of funds from the bank to the public is underfunded.

Collection and distribution of funds to the Bank Nagari Sharia Branch Padang using the concept of Mudharabah, the shape of the distribution of funds is based on the concept mudhrabah on Bank Nagari Sharia Branch is saving mudaraba, mudharabah deposits and demand deposits, form the distribution of the Bank Nagari Sharia Branch Padang is divided into three parts, namely Transactions financing are intended to have the goods to do with the principle of trading, financing transactions intended to get service done with the principle of leases, financing for the transaction of business cooperation aimed to obtain goods and services at the same time, the principle of profit sharing.

Keywords: the collection and distribution of funds is based on the concept of Mudharabah.

I

\section{PENDAHULUAN}

Menurut Undang-Undang No.7 tahun 1992 telah diperbaharui menjadi UndangUndang No.10 Tahun 1998 pengertian bank umum adalah bank yang melaksanakan kegiatan usaha secara konvensional dan atau berdasarkan prinsip syariah yang dalam kegiatannya memberikan jasa dalam lalu lintas pembayaran. Pasal 1 ayat 4 UndangUndang No.10 tahun 1998 pengertian BPR adalah bank yang melaksanakan kegiatan usaha secara konvensional atau berdasarkan prinsip syariah yang dalam kegiatannya tidak memberikan jasa dalam lalu lintas pembayaran.

Undang-Undang No.21 tahun 2008 tentang perbankan syariah dan PP RI No.72 tahun 1992 tentang bank berdasarkan prinsip bagi hasil serta dikeluarkannya fakta bunga haram dari Majelis Ulama Indonesia (MUI) tahun 2003. Banyak bank yang menjalankan operasionalnya secara prinsip syariah dengan diperkenalkannya jenis bank dengan prinsip bagi hasil. Maka dalam sistem perbankan Indonesia selain bank umum yang di kenal selama ini, dapat pula memiliki kegiatan usaha berdasarkan sistem bagi hasil. 
Perbedaan prinsip perbankan konvensional dengan bank bagi hasil terletak pada sistem bunga. Bank bagi hasil dalam menjalankan operasinya tidak menggunakan sistem bunga sebagai dasar untuk menentukan imbalan yang akan

diterima atas jasa pembiayaan yang diberikan. Demikian pula imbalan yang diberikan kepada nasabah atas dana yang dititipkan kepada bank. Penentuan imbalan yang diinginkan dan yang akan diberikan tersebut semata didasarkan pada prinsip bagi hasil.

Tabel 1

Penghimpunan Dana Pada Bank Nagari Cabang Syariah Padang Tahun 2013-2015

( Dalam Rp )

\begin{tabular}{cccc}
\hline Tahun & Tabungan & Deposito & Giro \\
\hline 2013 & 23.800 .829 .000 & 26.640 .870 .000 & 2.861 .156 .561 \\
2014 & 23.636 .198 .146 & 32.566 .780 .000 & 2.068 .433 .598 \\
2015 & 28.229 .308 .183 & 84.308 .380 .000 & 1.997 .130 .225 \\
\hline \multirow{2}{*}{ Total } & 75.666 .335 .329 & 143.516 .030 .000 & 6.926 .720 .384 \\
\hline
\end{tabular}

Sumber : Bank Nagari Cabang Syariah Padang

Dari tabel diatas dapat dilihat bahwa proses penghimpunan dana yang dilakukan oleh Bank Nagari Syariah Cabang Padang berfluktuasi setiap tahunnya, artinya mengalami turun naik. penghimpunan dana Bank Nagari Syariah Cabang Pariaman. Dari tabel diatas aktivitas penghimpunan dana bank nagari syariah cabang padang terlihat lebih banyak dana dari total deposito dari pada tabungan dan giro, yaitu sebesar Rp. 143.516.030.000,00, artinya masyarakat padang lebih banyak memilih produk deposito dari pada tabungan dan giro, sehingga total penghimpunan dana dalam bentuk deposito jumlahnya besa

Tabel 2

Penyaluran Dana Pada Bank Nagari Cabang Syariah Padang Tahun 2013 sampai 2015

( Dalam Rp )

\begin{tabular}{ccc}
\hline Tahun & $\begin{array}{c}\text { Investasi } \\
\text { Mudharabah }\end{array}$ & $\begin{array}{c}\text { Modal kerja } \\
\text { Mudharabah }\end{array}$ \\
\hline 2013 & 10.846 .518 .000 & 24.613 .215 .000 \\
2014 & 13.438 .165 .000 & 30.763 .256 .000 \\
2015 & 21.365 .862 .000 & 84.365 .364 .000 \\
\hline Total & 45.650 .545 .000 & 139.741 .835 .000 \\
\hline
\end{tabular}

Sumber: Bank Nagari Syariah Cabang Padang

Dari tabel diatas dapat disimpulkan bahwa aktivitas penyaluran dana konsep mudharabah pada Bank Nagari Cabang Syariah Padang mengalami kenaikan dari tahun ke tahunnya. Artinya proses penyaluran dananya berjalan dengan lancar.

Bank Nagari Cabang Syariah Padang merupakan salah satu bank syariah di Indonesia yang menjalankan konsep mudharabah berdasarkan PSAK 105. Bank Nagari Syariah cabang Padang memberikan bantuan pembiayaan dalam bentuk pembayaran 
secara kredit atau cicilan dan mempunyai beberapa sistem, prosedur dan persyaratan yang harus dipenuhi oleh calon debitur. Jenis produk dana yang dikembangkan oleh Bank Nagari Cabang Syariah Padang adalah jenis produk mudharabah yang berlandaskan kepada system bagi hasil yang merupakan kegiatan yang banyak diminati oleh masyarakat diantaranya adalah Deposito Mudharabah. Sedangkan pembiayaan dilakukan dalam bentuk pemberian pinjaman.

Konsep mudharabah merupakan akad kerjasama antara penyedia dana (shahibul maal) menyediakan modal $100 \%$ dengan pengelola usaha (mudharib) untuk memperoleh hasil usaha sesuai dengan pembagian hasil usaha berdasarkan porsi (nisbah) yang disepakati pada awal akad.

Secara teoritis pemberian pembiayaan yang dilakukan oleh bank syariah tidak memiliki resiko pembiayaan macet yang cukup tinggi karena pembiayaan dilakukan atas hukum syariah, namum seringkali dalam pelaksanaan nya sistem ini masih juga mengandung resiko pembiayaan macet yang disebabkan nasabah yang mengajukan permohonan pembiayaan ternyata tidak layak diberikan pembiayaan. Dengan demikian diperlukannya informasi yang mendukung pengawasan serta analisa didalam prosedur pemberian pembiayaan.

Prinsip bagi hasil merupakan karakteristik umum dan landasan bagi operasional bank islam secara keseluruhan. Secara Syari'ah, prinsipnya berdasarkan kaidah Al mudharabah, yang berdasarkan prinsip ini, bank syari'ah akan berfungsi sebagai mitra, baik dengan penabung, dengan pengusaha yang meminjam dana. Dengan penabung, bank akan bertindak sebagai mudharib (pengelola), sedangkan penabung bertindak sebagai shohibul maal (penyandang dana). Antara keduanya di adakan akad mudharabah yang mengadakan keuntungan masing-masing pihak, di sisi lain pengusaha atau peminjam dana bank syari'ah akan bertindak sebagai shohibul maal (penyandang dana), baik yang berasal dari penabung ataupun deposito maupun dana bank sendiri berupa modal pemegang saham. Sementara itu, pengusaha atau peminjam akan berfungsi sebagai mudharib (pengelola) karena melakukan usaha dengan cara memutar dan mengelola dana bank. Oleh karena itu dibutuhkan sebuah upaya dalam mencapai target yang telah direncanakan pihak bank agar sesuai dengan prosedur yang telah ditetapkan.

Sesuai dengan judul diatas, maka masalah yang dibahas dalam tugas akhir adalah : Bagaimana "Penghimpunan Dan Penyaluran Dana Berdasarkan Konsep Mudharabah Di Bank Nagari Cabang Syariah Padang”.

\section{LANDASAN TEORI \\ Pengertian Bank}

Menurut Undang-Undang Nomor 10 Tahun 1998 yang dimaksud dengan bank adalah badan usaha yang menghimpun dana dari masyarakat dalam bentuk kredit dan atau bentuk-bentuk lainnya dalam rangka meningkatkan taraf hidup rakyat banyak.

\section{Jenis-Jenis Bank}

\section{Bank umum}

Bank umum adalah bank yang melaksanakan kegiatan usaha secara konvesional dan atau berdasarkan prinsip syariah yang dalam kegiatannya dalam kegiatannya memberikan jasa dalam lalu lintas pembayaran.

2. Bank Pengkreditan Rakyat (BPR) 
Bank Pengkreditan rakyat (BPR) adalah bank yang melaksanakan kegiatan usaha secara konvensional atau berdasarkan prinsip syariah yang dalam kegiatannya tidak memberikan jasa dalam lalu lintas pembayaran.

\section{Fungsi Bank Syariah}

1. Fungsi Bank Syariah sebagai manajemen investasi

Bank-bank syariah dapat melaksanakan fungsi ini berdasarkan kontrak mudharabah atau kontrak perwakilan.

2. Fungsi Bank Syariah sebagai Jasa Keuangan

Bank Syariah dapat juga menawarkan berbagai jasa keuangan lainnya berdasarkan wupah (fee based) dalam sebuah kontrak perwakilan atau penyewaan. Contohnya, garansi,transfer kawat, L/C,dan sebagai nya.

\section{Sumber-Sumber Dana Bank}

Sumber-sumber dana bank dibagi atas tiga bagian yaitu :

1. Dana pihak pertama

Dana pihak pertama adalah dana yang bersumber dari pemegang saham atau pemilik.

2. Dana Pihak Kedua

Sumber dana ini merupakan tambahan jika bank mengalami kesulitan dalam pencarian sumber dana lainnya, sumber dana ininrelatif lebih mahal dan sifatnya hanya sementara waktu saja, sumber dana ini diperoleh dari kredit liquiditas dari bank indonesia, pinjaman antar bank, repurchasee agreement, fasilitas diskonto, pinjaman dari lembaga bukan bank, dan yang lainnya.

3. Dana Pihak Ketiga

Sumber dana ini merupakan sumber dana yang berasal dari masyarakat seperti giro, tabungan, dan deposito.

\section{Nama produk Tabungan Bank Nagari Cabang Syariah Padang}

1. Tabungan Mudharabah

Prinsip lain yang digunakan Bank syariah cabang Pariaman dalam menghimpun dana adalah dengan memakai prinsip investasi. Akad yang sesuai dengan prinsip ini adalah mudharabah. Yang dimaksud dengan tabungan mudharabah adalah tabungan yang dijalankan berdasarkan akad mudharabah. Disini Bank Nagari Cabang Syariah Padang sebagai Mudharib (pengelola dana) dan nasabah sebagai Shaibul mal (pemilik dana).

2. Tabungan Sikoci Syariah

Tabungan Sikoci Syariah adalah simpanan dana pihak ketiga pada Bank berdasarkan prinsip wadiah dan mudharabah untuk perorangan, badan usaha/hukum yang penarikannya hanya dapat dilakukan menurut syarat tertentu yang disepakati, namun tidak dapat ditarik dengan Cek, Bilyet Giro, atau alat pembayaran lainnya yang dapat dipersamakan dengan itu.

3. Tabungan Tahari Syariah

Tabungan Tahari Syariah adalah simpanan dana pihak ketiga pada Bank berdasarkan prinsip wadi'ah dan mudharabah untuk perorangan (muslim dan muslimah) yang akan melaksanakan ibadah haji yang penarikannya tidak dapat dilakukan sewaktuwaktu kecualli dalam rangka penarikan rekening.

5. Deposito Mudharabah 
Deposito Mudharabah adalah simpanan dana pihak ketiga kepada bank berdasarkan prinsip Mudharabah untuk perorangan, badan usaha/hukum atau pemerintah yang penarikanya hanya dapat dilakukan pada waktu tertentu sesuai perjanjian nasabah dengan bank.Deposito ini memiliki ciri-ciri pokok yaitu jangka waktu penarikanya tetap, dan bisa diuangkan pada saat jatuh tempo oleh pihak yang namanya tercantum dalam bilyet deposito, karena deposito merupakan simpanan berjangka yang diatas namakan.

6. Giro Mudharabah

Yang dimaksud dengan giro mudharabah adalah giro yang dijalankan berdasarkan akad mudharabah. Mudharabah mempunyai dua bentuk, yakni mudharabah mutlaqah dan mudharabah muqayadah, yang perbedaan utama diantara keduanya terletak pada ada atau tidaknya persyaratan yang diberikan pemilik dana kepada bank dalam mengelolah hartanya, baik dari sisi tempat, waktu, maupun objek investasinya.

\section{HASIL DAN PEMBAHASAN}

\section{Bentuk - bentuk Pembiayaan Mudharabah}

\section{Pembiayaan investasi mudharabah}

Pembiayaan investasi mudharabah di Bank Nagari Cabang Syariah Padang merupakan pembiayaan yang diberikan oleh bank sebagai pemilik dana kepada nasabah sebagai pengelola yang digunakan untuk keperluan investasi, memenuhi kebutuhan barang-barang modal serta fasilitas-fasilitas yang erat kaitannya dengan investasi sendiri.

\section{Pembiayaan Modal Kerja mudharabah}

Pembiayaan modal kerja mudharabah di Bank Nagari Cabang Syariah Padang yaitu, pembiayaan untuk memenuhi kebutuhan modal kerja yang bertujuan untuk peningkatan produksi maupun untuk keperluan dagang dimana bank sebagai pemilik dana memberikan dana sepenuhnya kepada nasabah sebagai pengelola.

Untuk melihat Aktivitas Penyaluran Dana Pada Bank Nagari Cabang Syariah

Padang dapat dilihat pada tabel dibawah ini:

1. Sharf (jual beli valuta asing )

Pada prinsipnya jual beli valuta sing sejalan dengan prinsip sharf. Jual beli mata uang yang tidak sejenis ini, penyerahannya harus dilakukan pada waktu yang sama. Bank mengambil keuntungan dari jual beli valuta sing ini.

2. Ijarah ( sewa)

Jenis kegiata ijarah antara lain penyewaan kotak simpanan (safe deposit box) dan jasa tarlaksana administrasi dokumen, bank dapat imbalan sewa dari jasa tersebut.

Transaksi jual beli dapat dibedakan berdasarkan bentuk pembayaran dan bentuk penyerahan, yakni sebagai berikut:

1. Pembiayaan Mudharabah

Jual beli murabahah secara terminologi adalah pembiayaan saling menguntukan yang dilakukan oleh pihak penawar dengan pihak yang membutuhkan melalui transaksi jual beli dengan nilai lebih yang merupakan keuntungan atau laba bagi penawar.

Rukun:
a. ada penjual
b. ada pembeli
c. objek yang dijual-belikan 
d. ada harga

e. akad

syarat :

1) pembeli dan penjual ada dalam cakap hukum

2) barang tidak termasuk yang diharamkan

3) barang sesuai spesifikasi pembeli

4) barang awalnya syah dimiliki penjual

Contoh :

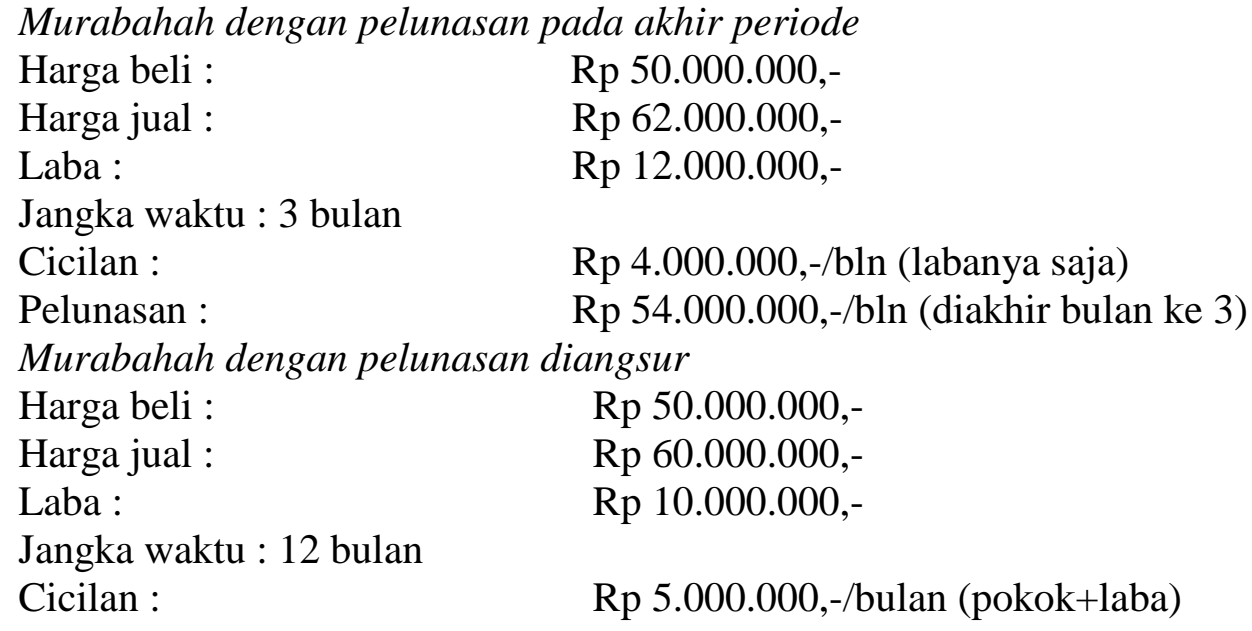

Berdasarkan komposisi share modal bank dalam usaha nasabah, terdapat dua pola pembayaran yaitu :

1. Mudharabah

Mudharabah atau qirad adalah penyerahan sejumlah harta tertentu kepada seseorang utuk diusahakan. Laba yang diperoleh dibagi dua sesuai dengan syarat-syarat yang telah disepakati. Sedangkan ruginya hanya dibebankan kepada pemilik modal, sementara pelaksana hanya menanggung rugi atas tenaga(upaya) dan waktunya.

a. Rukun mudharabah menurut ulama syafi'iyah::

b. Pemilik barang

c. Pekerja (orang yang mengelola)

d. Akad mudharabah

e. Maal, harta pokok atau modal

f. Amal, pekerjaan pengelolaan harta yang menghasilkan laba

g. Keuntungan

Ketentuan umum skema pembiayaan mudharabah adalah sebagai berikut ::

1. Jumlah modal yang diserahkan kepada nasabah selaku pengelola modal harus diserahkan tunai, dan dapat berupa uang atau barang

2. Hasil dari pengelolaan modak pembiayaan mudharabah dapat diperhitungkan dengan cara::

a. Perhitungan dari pendapatan proyek

b. Pendapatan dari keuntungan proyek

3. Hasil usaha dibagi sesuai dengan persetujuan dalam akad. Bank sebagai pemilik modal menanggung seluruh kerugian kecuali akibat kelalaian dan penyimpangan pihak nasabah seperti penyalahgunaan dana.

4. Bank berhak melakukan pengawasan terhadap pekerjaan, namun tidak berhak mencampuri urusan pekerjaan/usaha nasabah. Jika nasabah cedera 
janji dengan sengaja, misalnya tidak mau membayar kewajiban atau menunda pembayaran kewajiban, maka ia dapat dikenakan sanksi administrasi.

\section{Penghimpunan dana berdasarkan konsep mudharabah}

1. Tabungan Mudharabah

Tabungan adalah simpanan yang penrikannya hanya dapat dilakukan menurut syarat tertentu yang disepakati, tetapi tidak dapat ditarik dengan cek atau alat yang dipersamakan dengan itu.

2. Deposito Mudharabah

Depisito adalah investasi dana berdasarkan akad mudharabah yang tidak bertentangan dengan prinsip syariah yang penarikannya hanya dapat dilakukan hanya pada waktu tertentu berdasarkan akad antara nasabah (penyimpan) dengan bank syariah (Unit Usaha Syariah). Perbedaannya dengan deposito konvensional adalah terlihat pada akad dan sistem bagi hasil yang ditawarkan.

\section{Penyaluran Dana Berdasarkan Konsep Mudharabah}

Penyaluran dana pada nasabah di Bank Nagari Cabang Syariah Padang, secara garis besar produk pembiayaan syariah terbagi kedalam tiga kategori yang dibedakan berdasarkan tujuan pengunaan nya yaitu,

1. Transaksi pembiayaan yang ditujukan untuk memiliki barang dilakukan dengan prinsip jual beli.

2. Transaksi pembiayaan yang ditujukan untuk mendapatkan jasa dilakukan dengan prinsip sewa.

3. Transaksi pembiayaan untuk usaha kerjasama yang ditujukan guna mendapatkan sekaligus barang dan jasa,dengan prinsip bagi hasil.

Pada kategori pertama dan kedua, tingkat keuntungan bank di tentukan di menjadi bagian harga atas barang atau jasa yang dijual. Produk yang termasuk dalam kelompok ini adalah produk yang menggunakan prinsip jual beli seperti murabahah,salam, dan istishna serta produk yang mengunakan prinsip sewa yaitu ijarah. Sedangkan pada kategori ketiga, tingkat keuntungan ditentukan oleh prinsip nisbah bagi hasil yang disepakati di muka. Produk perbankan yang termasuk ke dalam kelompok ini adalah musyrakah dan mudharabah.

Secara spesifik di Bank Nagari Cabang Syariah Padang terdapat bentuk musyarakah yang popular dalam produk perbankan syariah yaitu mudharabah. Mudharabah adalah bentuk kerjasama antara dua atau lebih pihak dimana pemilik modal (shahibul maal) mempercayakan sejumlah modal kepada pengelola (mudharib) dengan suatu perjanjian pembagian keuntungan. Bentuk ini menegaskan kerjasama dengan kontribusi $100 \%$ modal dari shahibul maal dan keahlian dari mudharib.

Transaksi jenis ini tidak mensyaratkan adanya wakil shahibul maal dalam manajemen proyek. Sebagai orang kepercayaan, mudharib harus bertindak hati-hati dan bertanggung jawab untuk setiap kerugian yang terjadi akibat kelalaian. Sedangkan sebagai wakil shahibul maal dia diharapkan untuk mengelola modal dengan cara tertentu untuk menciptakan laba optimal.

Perbedaan yang esensial dari musyarakah dan mudharabah terletak pada besarnya kontribusi atas manajemen dan keuangan atau salah satu diantara itu. Dalam mudharabah modal hanya berasal dari satu pihak, sedangkan dalam musyarakah modal berasal dari dua pihak atau lebih. musyarakah dan mudharabah dalam literatur fiqih 
berbentuk perjanjian kepercayaan (uqud al amanah) yang menuntut tingkat kejujuran yang tinggi dan menjunjung keadilan. Karenanya masing-masing pihak harus menjaga kejujuran untuk kepentingan bersama dan setiap usaha dari masing-masing pihak untuk melakukan kecurangan dan ketidakadilan pembagian pendapatan betul-betul akan merusak ajaran Islam.

Dibawah ini digambarkan alur operasional dalam proses penyaluran dana berdasarkan konsep mudharabah dari pemilik dana sampai ke nasabah pengelola modal dengan sistem bagi hasil.

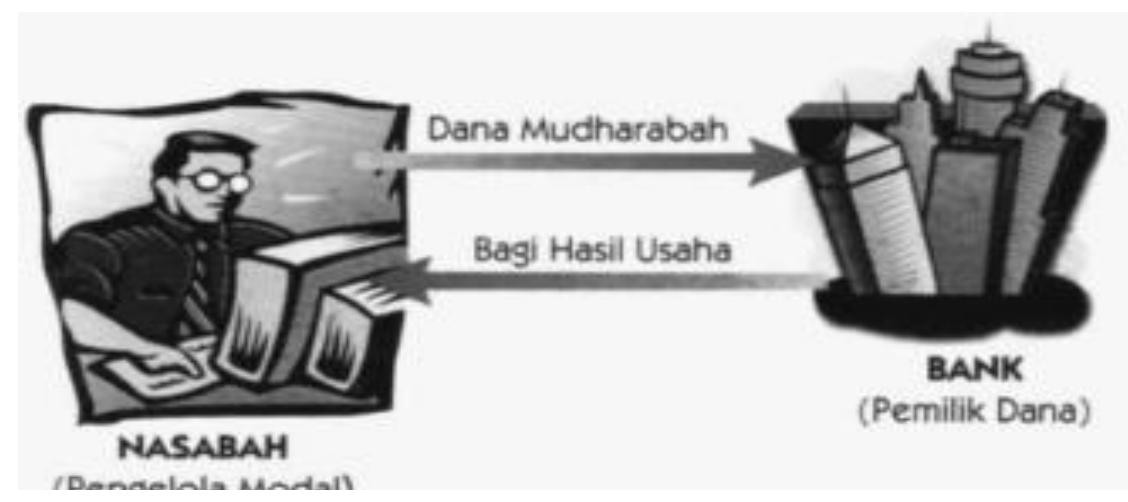

Ketentuan umum:

1. Jumlah modal yang diserahkan kepada nasabah selaku pengelola modal; harus diserahkan tunai, dapat berupa uang atau barang yang dinyatakan nilainya dalam satuan uang. Apabila modal diserahkan secara bertahap, harus jelas tahapannya dan disepakati bersama.

2. Hasil dan pengelolaan modal pembiayaan mudharabah dapat diperhitungkan dengan dua cara:

a. Perhitungan dari pendapatan proyek (revenue sharing)

b. Perhitungan dari keuntungan proyek (profit sharing)

3. Hasil usaha dibagi sesuai dengan persetujuan dalam akad, pada setiap bulan atau waktu yang disepakati. Bank selaku pemilik modal menanggung seluruh kerugian kecuali akibat kelalaian dan penyimpangan pihak nasabah, seperti penyeleweng-an, kecurangan dan penyalahgunaan dana.

Bank berhak melakukan pengawasan terhadap pekerjaan namun tidak berhak mencampuri urusan pekerjaan/usaha nasabah. Jika nasabah cidera janji dengan sengaja misalnya tidak mau membayar kewajiban atau menunda pembayaran kewajiban, dapat dikenakan sanksi

Selain itu Al-mudharabah pada dasarnya adalah perjanjian kerjasama antara dua pihak atau lebih di mana salah satu pihak menyediakan dana dan pihak lainnya menyediakan tenaga atau keahlian. Antonio mendefinisikan al-mudharabah sebagai suatu perjanjian kerjasama antara dua pihak di mana pihak pertama (pemilik modal atau shahibul maal) menyediakan seluruh kebutuhan modal, sedangkan pihak lainnya menjadi pengelola (mudharib). Keuntungan usaha yang diperoleh akan dibagi berdasarkan perjanjian atau kesepakatan. Sebaliknya apabila usaha mengalami kerugian yang disebabkan bukan karena kesalahan atau kelalaian pihak pengelola (mudharib), kerugian tersebut merupakan tanggung jawab pemilik modal (shahibul maal).

Siamat mengemukakan bahwa prinsip al- mudharabah dapat digolongkan ke dalam dua jenis, yaitu al-mudharabah muthlaqah dan al-mudharabah muqayyadah. 
Implementasi konsep al-mudharabah muthlaqah dalam perbankan syariah diatur sebagai berikut:

1. Jumlah modal yang diserahkan kepada nasabah selaku pengelola modal harus berupa uang tunai. Apabila modal diserahkan secara bertahap, tahapannya harus jelas dan disepakati bersama.

2. Hasil dari pengelolaan modal pembiayaan mudharabah diperhitungkan dengan cara:

a. Perhitungan dari pendapatan proyek (revenue sharing)

b. Perhitungan dari keuntungan proyek (profit sharing)

c. Hasil usaha dibagi sesuai dengan persetujuan dalam akad, pada setiap bulan atau waktu yang disepakati. Bank selaku pemilik modal menanggung seluruh kerugian kecuali akibat kelalaian dan penyimpangan pihak nasabah, seperti penyelewengan, kecurangan, dan penyalahgunaan dana.

d. Bank berhak melakukan pengawasan terhadap pekerjaan namun tidak berhak mencampuri urusan pekerjaan/usaha nasabah. Jika nasabah cidera janji dengan sengaja, misalnya tidak mau membayar kewajiban, atau menunda pembayaran kewajiban, dapat dikenakan sanksi administrasi

\section{METODE PENELITIAN}

1. Metode Pengumpulan Data

a. Studi Pustaka (Library Research)

Penelitian yang dilakukan dngan membaca beberapa buku-buku ilmiah dan tulisan-tulisan yang berhubungan dengan pembahasan yang dilakukan.

b. Studi Lapangan (Field Research)

Penelitian yang langsung objek penelitian di pilih untuk meneliti hasil data primer. Penelitian langsung ke lapangan ini akan dapat membantu penulis untuk melengkapi data yang diperlukan. Adapun cara riset lapangan ini adalah dengan mewawancarai pihak-pihak yang berkepentingan dalam hal ini adalah perusahaan atau instansi terkait.

b) Metode Analisa Data

Dalam menganalisa data, penulis menggunakan metode analisa data kualitatif sebagai metode penulisan yang menjelaskan secara deskriptif mengenai Penghimpunan Dan Penyaluran Dana Berdasarkan Konsep Mudharabah Di Bank Nagari Cabang Syariah Padang. Metode analisa ditinjau dari dua segi berbeda yaitu antara teori dan praktek yang perlu dipertemukan sehingga dapat diketahui sejauh mana pelaksanaannya, apakah perbedaan yang timbul menyangkut prinsip dasar konsep itu sendiri.dengan menganalisa perbandingan, pertanyaan itu akan terjawab selanjutnya dan hasil analisa itu dipergunakan sebagai dasar pengambilan kesimpulan dan saran.

\section{SIMPULAN}

Berdasarkan hasil penelitian yang telah penulis lakukan pada Bank Nagari Cabang Syariah Padang, dapat ditarik kesimpulan sebagai berikut

1. Penghimpunan dana dengan konsep mudharabah yang dilakukan oleh Bank Nagari Syariah Cabang Padang mengalami kenaikan, baik itu kita lihat penghimpunan dana dan penyaluran dana pada bank nagari cabang syariah padang. Lebih banyak digemari oleh warga padang, dengan perbandingan yang jauh lebih tinggi dari bank 
konvensional. Disini dapat disimpulkan bahwa masyarakat padang lebih banyak menghimpun dan Penghimpunan dana dengan konsep mudharabah.

2. Penyaluran dana dengan konsep mudharabah pada bank nagari cabang syariah padang mengalami kenaikan dari tahun ke tahun. Artinya proses penyaluran dananya berjalan dengan lancar. Penyaluran dana mudharabah dalam bentuk pembiayaan investasi maupun modal kerja merupakan tugas pokok untuk mendapatkan keuntungan. Semakin banyak pembiayaan yang diberikan maka semakin banyak keuntungan yang akan diperoleh Bank Nagari Cabang Syariah Padang.

3. Proses penghimpunan dana yang dilakukan oleh Bank Nagari Syariah Cabang Padang berfluktuasi setiap tahunnya, artinya mengalami turun naik. penghimpunan dana Bank Nagari Syariah Cabang Padang tahun 2013 ke tahun 2014 . Untuk Tabungan turun sebesar $\mathrm{Rp}$ 164.630.854,00, Deposito naik sebesar Rp. 5.925.910.000,00 ,dan Giro naik sebesar Rp. 792.722.963,00. sedangkan pada tahun 2014 ke tahun 2015 mengalami naik yaitu tabungan sebesar Rp. 4.593.110.037,00 ,Deposito sebesar Rp. 51.741.600.000,00 , dan untuk Giro turun sebesar Rp. 71.303.373,00. Dari tabel diatas aktivitas penghimpunan dana bank nagari syariah cabang padang lebih banyak dana dari total deposito dari pada tabungan dan giro, yaitu sebesar Rp. 143.516.030.000,00, artinya masyarakat padang lebih banyak memilih produk deposito dari pada tabungan dan giro, sehingga total penghimpunan dana dalam bentuk deposito jumlahnya besar.

4. Dari tabel diatas dapat disimpulkan bahwa aktivitas penyaluran dana konsep mudharabah pada bank nagari syariah cabang padang mengalami kenaikan dari tahun ke tahunnya. Artinya proses penyaluran dananya berjalan dengan lancar. Karena penyaluran dana dalam bentuk pemberian pembiayaan, baik pembiayaan investasi maupun modal kerja merupakan tugas pokok untuk mendapatkan keuntungan. Semakin banyak pembiayaan yang diberikan maka semakin banyak keuntungan yang akan diperoleh Bank Nagari Syariah Cabang Padang.

5. Bank Nagari cabang syariah padang mengalami peningkatan setiap tahunnya.

\section{DAFTAR PUSTAKA}

Afriyeni, A. Fernos, J (2018). Analisis Faktor-Faktor Penentu Kinerja Profitabilitas Bank Perkreditan Rakyat (BPR) Konvensional Di Sumatera Barat. Jurnal Benefita: Ekonomi Pembangunan Manajemen Bisnis Dan Akuntansi. Volume 3. No. 3. http://doi.org/10.22216/jbe.v3i3.3623

Ascaraya, (2007). Akad dan Produk Bank Syariah, Raja Grafindo Persada Jakarta.

Jundiani. Pengaturan Hukum Perbankan Syariah Di Indonesia. Malang : UIN. Malang Press.2009.

Karim, Adiwarman, (2004).BANK ISLAM, Analisis fiqih dan keuangan. PT.Raja Grafindo Persada: Jakarta. 
Marlius, D. (2018). Loyalitas Nasabah Bank Nagari Syariah Cabang Bukittinggi Dilihat Dari Kualitas Pelayanan. Jurnal Pundi. Volume 1. No. 3. Hal.1222. https://doi.org/10.31575/jp.v1i3.60

Muhammad, M.Ag, (2005). Pengantar Akuntansi Syariah. PT Salemba. Empat Patria, Jakarta.

Pemerintah Republik Indonesia,(2008) Undang-Undang Perbankan Nomor 10 Tahun 1998 Tentang Perubahan Undang-Undang Nomor 7 Tahun 1992 Tentang. Sinar Grafika, Jakarta.

Syafe'I Antonio, Muhammad. (2001). Bank Syariah dari Teori ke Praktek. Jakarta: Gema Insani

Jundiani. Pengaturan Hukum Perbankan Syariah Di Indonesia. Malang : UIN. Malang Press.2009. 